\title{
A VIA INVESTIGATIVA DA FILOSOFIA DO SER E O FENÔMENO JURÍDICO
}

\author{
Jeannette Antonios Maman \\ Professora Doutora do Departamento de Filosofia \\ e Teoria Geral do Direito da Faculdade de Direito \\ da Universidade de São Paulo.
}

Resumo:

Noçōes de fenômeno e fenomenologia da filosofia do ser, de Martin Heidegger indicam novo acesso ao fenômeno jurídico.

Abstract:

Notions of phenomenon and phenomenology of the philosophy of the being. of Martin Heidegger. indicate a new access to the legal phenomenon.

Unitermos: Heidegger; fenomenologia; funômeno jurídico.

Keywords: Heidegger; phenomenology: phenomenon.

I. Des-velamento do mundo jurídico.

Falar sobre alternativas para o direito, aquele dircito tal como em geral se entende, conjunto de normas juridicas (direito posto pelo Estado, legislação, regulação) implica tomar o objeto desta reflexão, o direito, como fenômeno manifesto à nossa compreensão - fenômeno aqui, é o que se mostra, se estende diante de nós, acontece; não tomamos conhecimento dele em decorrência de um raciocínio apriorístico, mas de modo imediato. como percepção originaria e primitiva.

O que nos envolve e é todo o mundo ambiente, não só a natureza física, é o mundo no conjunto de todos seus entes - sempre nos encaminha a decisões e escolhas, que resultam pois, em injunções (aquilo que une no mesmo sentido, que nos permite encontrar as trilhas). O que nos une na busca da verdade, diante dos olhos, está na proximidade e na expressão dos fenômenos.

Pensamos apontar aqui uma nova linha de pesquisa jus-filosófica, utilizando os caminhos da filosofia heideggeriana e a fenomenologia como método. 
A contribuição deste pequeno artigo é muito provável que esteja na motivação dos estudos de filosofia em Heidegger.

Martin Heidegger não foi um fillósofo do direito, fez filosofia como atividade de um pensar inquieto diante das perplexidades de um mundo que nos constitui.

Jose Gaos, na edição mexicana da tradução de Ser c o Tempo, (Fondo de Cultura Economica) afirma ser esta uma das obras capitais da filosofia de nossos dias, senão a mais influente e original da filosofia na atualidade. Sem Heidegger não haveria Sartre, Foucault, Derrida ou outros estudiosos de sua obra, com influências declaradas ou-não.

Ao pastorcio de suas idéias, muitos pensadores europeus se dedicaram. Aqui entre nós, muito especialmente na Faculdade de Direito da Universidade de São Paulo, foram objeto de estudo do professor Aloysio Ferraz Pereira, na sua obra Estado $e$ Direito na perspectiva da libertação e, em decorrência de dialogo que nos levou a avançar na compreensão do fenômeno jurídico, como sua orientanda, resulta a tese que a autora publicou, sob o título: Fenomenologia existencial do direito. Assim, vamos trabalhar com duas expressões: fenomenologia e fenômeno. O objetivo é fixálas para tornar a compreensão do método possivel. Não pensamos esgotar a matéria, mas apenas anunciá-la (o anúncio já é manifestação, no sentido heideggeriano).

II. Fenomenologia e Fenômeno.

1. Fenomenologia.

Fenomenologia existencial do direito é linha de pesquisa que investiga, na árca do direito e do Estado, as estruturas existenciais do fenômeno jurídico. A filosofia do ser ou a filosofia da existência, na trilha heideggeriana, permitem contestar as tradicionais correntes do pensamento ocidental, sobre direito e justiça. Deixamos o racionalismo e o conscrvadorismo das tradicionais correntes jusfilosóficas, não para cair no irracionalismo, mas para privilegiar a estrutura da experiência juridica, na analitica existencial do ser-justo, da justiça como vivência juridica. 
A fenomenologia de Husserl, desenvolvida a partir de suas Investigações Lógicas (1900 - 1901), e em seus seminários cartesianos (Sorbonne 1937) e a de Hartmann (Filosofía da consciência mural - 1879) são ciências de essências (no sentido de idéias. formas, eidética, ao que se reduz) e não da experiência fática. Resultam em diversas correntes, como a racionalista de Merleau Ponty e a empirista de Heidegger.

"A palavra fenomenologia significa antes de mais nada um conceito de método. Ela não caracteriza a consistência de fato do objeto da indagação filosófica, mas seu como... Esse termo expressa um lema que poderia ser assim formulado: às coisas mesmas! por oposição às construções soltas no ar e aos achados casuais: em oposição à admissão de conceitos apenas aparentemente verificados e aos falsos problemas que se impõem de geração em geração como problemas verdadeiros" SZ $\left(\S 7^{\circ}\right)$.

A fenomenologia de Heidegger não se reduz à melodologia, já que serve à compreensão do que ele chama de ontologia fundamental (SZ): o mais importante na busca pelo ser dos entes. $\mathrm{SZ}\left(\S 7^{\circ}\right)$.

O que isto importa para o jus-filósofo?

Para a linguagem juridica vale dizer: importa a experiência contida na palavra, vale dizer: a possibilidade de efetividade jurídica, quando o modo de ser encontra abrigo na linguagem.

2. Fenômeno.

Para Heidegger fenômeno tem no significado de aparecer, parecer e aparência, já incluido o significado originário de fenômeno como o que se revela, que sustenta e fundamenta o anterior significado.

O sentido finomenológico de fenômeno é para Heidegger o aparecer puro e simples do ser em si, distinguindo-se da simples aparência, que indica o ser ou 
aponta para o ser, que entretanto, ainda não se mostra, ou se esconde. Neste sentido, a noção de manifestação como fenômeno não se opõe à coisa em si, não é a aparência da coisa, mas é a coisa identificada em seu ser.

Explique-se: fenômeno, na sua origem grega, resulta do verbo mostrarse, o que faz com que fenômeno seja o que se revela, o que se mostra em si mesmo, não só no seu modo de aparecer, parecer e aparência, mas na sua interioridade, muitas vezes oculta pelo véu do aparente, levando-nos ao caminho investigativo desta verdade interior.

Podemos assim dizer que fenômeno é o que se manifesta em si mesmo.

"O fenômeno, mostra-se em si mesmo, significa um modo privilegiado de encontro. Manifestação, ao contrário, indica no próprio ente uma remissão referencial, de tal maneira que o referente (o que anuncia) só pode satisfazer a sua possivel função de referência se for um "fenômeno" ou seja, caso se mostre em si mesmo. Manifestação e aparência se fundam, de maneira diferente, no fenômeno. Essa multiplicidade confusa dos "fenômenos" que se apresenta nas palavras fenômeno, aparência, aparecer, parecer, manifestação, mera manifestação, só pode deixar de nos confundir quando se tiver compreendido, desde de o princípio, o conceito de fenômeno: o que se mostra em si mesmo" SZ $\left(\S 7^{\circ}-\mathrm{A}\right)$.

Já nas Investigações Lógicas de Husserl, fenômeno, indica não só o que aparece ou se manifesta ao homem em condições particulares, mas o que se manifesta em si mesmo, como em si, na sua essência. É bem verdade que não há manifestação espontânca ou natural da coisa, exige-se a investigação filosófica como fenomenologia. 
III. Pensar e compreender na via do fenômeno.

1. Pensar.

a) Não tomaremos como interpretação técnica do pensar (ÜH, 6), mero utilitário, transposição da hipótese para a práxis, mas pensar como experiência que precede toda postura cientifica. Onde fica este lugar? $\mathrm{O}$ lugar a partir do qual pensamos? Na proximidade dos objetos que continuamente providenciamos e com os quais nos relacionamos.

b) O lugar não como punto definido, mas como invenção, descoberta do percurso em idas e vindas. Disto decorre que todo projeto é temporário e implica deslocamento.

"Seria absurdo, daqui por diante, confirmar-se na ingenuidade e nos limites tranqüilizadores de uma tradição fechada sobre se mesma" (Gadamer O problema da consciência histórica).

2. Compreender.

Compreensão diante das possibilidades: a compreensão resulta em percepção imédiata, invenção, construção (não no sentido de constructo intelectual) no encontro das coisas, diante de nossos olhos reiteradamente, e na expectativa de um futuro, de um projeto, do sentido mais profundo da expressão humanismo. O debate no que me diz respeito, limita-se não ao esclarecimento, mas ao clarear a questão hermenêutica. Este lançar-nos à proximidade. é estar na mesma clareira, o que nos permite decidir diante das possibilidades. Aqui "indagar é a devoção do pensar"

São Paulo. dezembro de 2004. 
Bibliografia.

HEIDEGGER, Martin. El Ser y el Tiempo. México: Fondo de Cultura Economica, 2002.

Qu appelle- t.on penser? Quadrige. Paris: Presses Universitaires de France, 1992. Lettres sur l'humanisme. Texto bilíngüe. Paris: Aubier, 1957. . Carta sobre o humanismo. Lisboa: Guimarães Editores, 1987.

GADAMER. Hans-Georg. O problema da consciência histórica. Rio de Janeiro: Editora Fundação Getúlio Vargas, 1998. 